DOI https://doi.org/10.18551/rjoas.2018-11.30

\title{
CORPORATE SOCIAL RESPONSIBILITY IN PUBLIC RELATIONS: A STUDY OF STAKEHOLDERS' OPINIONS IN INDONESIA
}

\author{
Anggraini Choiria, Kriyantono Rachmat \\ University of Brawijaya, Indonesia \\ E-mail: choiriaanggraini@gmail.com
}

\begin{abstract}
Research using this quantitative method concentrates on being able to find out stakeholder opinions on the implementation of CSR programs carried out by five companies in Indonesia, namely: (1) PT. Energasindo, PT. Sharp, PT. Pertamina, PT. Hongkong and Sanghai Banking Corporation (HSBC), PT Perusahaan Gas Negara (PGN). This research was conducted in the work area of each company spread in several cities such as: Bekasi, Karwang, Medan, Pontianak, Yogyakarta, Jakarta, Tangerang, Sidoarjo, and Pangkal Pinang. The survey that researchers did combines three scales to understand community opinion on CSR programs that have been rolled out by several companies. The three scale indicators include the CSR Index built by Dedy Prayogo and Yosef Hilarius; Chopra's Kanji Corporate Social Responsibility by Kanji and Chopra; last is the scale adopted from ISO 26000. This research is important to find out the stakeholder opinion on the CSR program that has been rolled out by the company considering that this opinion will have implications for the reputation of the company by the public at large. The results of this study indicate that in general stakeholders provide good opinions on the practice of implementing CSR by companies in Indonesia. However, in practice, the sustainability program category has not received a good assessment. Referring to this, the researcher offers a way to communicate this to the public with the concept of community involvement. The implementation of community involvement as a form of applicative communication for public relations to be able to diologize with stakeholders through CSR
\end{abstract}

\section{KEY WORDS}

Corporate social responsibility, public relations, stakeholder management, opinion, survey, quantitative.

Sarman Simanjorang, Deputy I of the Organization and Institutional Affairs of the Central Board of the Social Welfare CSR Forum, said that not many companies in Indonesia are fully concerned about CSR (Wulandari, 2016). Though some researchers explain that CSR can help companies to promote company products (Arli and Tjiptono, 2013). Not only can it help promote products, CSR can also help communicate the company's identity to the public Verboven (2011). The other most important thing from the launch of CSR programs by companies can be a helper of the company when a crisis is caused by the public outrage (Kriyantono, 2015). Of course, if reviewed in more detail, this will have implications for public or community support for the sustainability of the company's operations.

This CSR will also have implications for the company's reputation and community support for the company. It also remembers that CSR is an important factor for consumers to assess the company's credibility and consideration in purchasing company products (Sen \& Bhattacharya, 2001; Vanhamme and Grobben, 2009) and especially for the mining and oil and gas industry, this program has a strategic position to build reciprocal relations between the corporation and its stakeholders (Prayogo, 2011). On a business basis, the results of the program evaluation can be used as an objective presentation of corporate social performance, which then becomes very useful to improve corporate image and consideration for potential investors to be able to collaborate with corporations (Orlitzky and John, 2001).

A similar statement was also conveyed by Regester and Larkin (2008) that three quarters of the population paid close attention to the company's reputation before buying products and $60 \%$ of consumers said that they avoided buying products from certain 
companies because they still doubted the company's social, ethical and environmental record. Especially if at a time when the company is in a crisis position, CSR can be used as a strategy to be able to maintain the company's reputation, namely as a crisis management tool (Coombs, 1995; Dincer and Dincer, 2013; Tesler and Malone, 2008; Vanhamme and Grobben, 2009), because each crisis raises public challenges about corporate social responsibility (Coombs, 2010; Ferguson, Wallace and Chandler, 2010).

In addition to the issue of community support and maintaining a reputation for harmony during the crisis, CSR is an important element of corporate dialogue with its stakeholders. Stakeholders in this context are groups of CSR stakeholders or more specifically researchers refer to the community. For the record, in this context the CSR beneficiary community of the company enters the company's external stakeholder section. This is evidenced by several studies which explain that many corporations rely on the end result of CSR (Bhattacharya, Kroschun, and Sen, 2009; Kriyantono, 2015) as an element of dialogue. Communities as part of stakeholders also become part of the overall strategic planning process in the organization (Freeman, 1984), because they are people who can influence and be influenced by company activities and decisions (Coombs, 2007; Dempsey, 2009; Freeman, 1984; and Grunig and Repper, 2008), including CSR activities.

In the context of communication, CSR is a long-term corporate social investment that is useful to build a corporate reputation in the eyes of stakeholders (Kriyantono, 2015; 2016), because it contributes positively to the improvement of social welfare (Bhattacharya, et al, 2009), not only for corporate benefits only, but also for employees, stakeholders, consumers, community, environment and society (Kanji and Chopra, 2010). Moreover, according to the presentation conveyed by the Register and Larkin (2008), the community is more likely to judge that the company is more socially responsible than just spending products at low prices. Harrison (2008) refers to this as a company performance that is defined as a demand for the company that the company not only produces and sells products but the company must also be able to manage its social and political environment.

However, this has not been well understood by companies in Indonesia. Evidently based on Sarman's explanation, there are only three companies that have good reputation in Indonesia, namely Unilever, Pertamina, and Telkom (Social Welfare CSR Forum, 2016). This is also reinforced by recent research which states that companies in Indonesia have a lower quality of corporate social responsibility (CSR) compared to Thai companies due to low company understanding of CSR practices (Suastha, 2016). So Sarman can classify that there are three types of companies in implementing CSR, namely: (1) companies that have committed to implement CSR, (2) companies that want to implement CSR but do not know how to channel it, (3) companies that only when asked to issue a program CSR (Thaha, 2016).

This statement was further strengthened by an explanation given by Eugene Tan, Codirector of the Center for Scholars Development Singapore Management University, that many companies that companies in ASEAN do not have regulations in implementing sustainable CSR (Suastha, 2016). However, this condition should be different from Indonesia because Indonesia already has a clear regulation for the implementation of CSR by its implementing companies is still low. Because of this, a research is needed to find out the implementation of CSR by companies in Indonesia, as expressed by Yanti Triwadianti, Chair of the ASEAN CSR Network, that the involvement of academics and research is an important key in encouraging sustainable business practices (Suastha, 2016). Specifically, more than that, there are facts that show that even though Indonesia has a regulation using the concept of mandatory approach to regulate corporate CSR activities, its implementation is still low and even only three corporations have a high commitment to CSR implementers and the company is wrong oil and gas is certainly a big question. Although Indonesia has obliged (mandatory approach) companies in Indonesia to implement CSR, but this cannot be used as a benchmark that the implementation of CSR in Indonesia is good (Kriyantono, 2015). Referring to these arguments and the facts conveyed that the 2016 Forkesos RI requires a study on the assessment of the implementation of CSR in Indonesia. One way to find out this 
assessment is through stakeholder opinion which in this context is represented by the beneficiary community towards CSR implementation activities.

Therefore, based on several empirical arguments and the facts above, it becomes important to do a research to see the opinions of CSR beneficiaries as part of the company's stakeholders. Because of this it is quite urgent to be able to do a research with a focus on the formulation of the problem about the company's stakeholder opinion about the CSR implementation activities by the company. The opinion of the beneficiary is an essential matter because the opinions expressed will show the legitimacy given by the community to the company. Legitimacy is obtained from the approval of communities around the organization (Habermas, 1975, quoted in Culbertson, et al., 1993) and is built on two aspects: organizational competence (organization's competence) and organizational character (Veil et al., 2005). In addition, it refers to the findings of research conducted by Shah and Chen (2010) that CSR as a social aspect of a company that gets a positive assessment from the community will be able to improve the credibility and reputation of the company. In this regard, the formulation of the problem is answered by one frame of quantitative research method with the positivistic paradigm.

\section{LITERATURE REVIEW}

Corporate Social Responsibility (CSR) is a form of corporate social responsibility to the community voluntarily to create social welfare that focuses more on economic problems (Siltaoja, Malin, and Pyykkonen (2015). Van Marrewijk (2003) further defines CSR as a relationship Corporate social responsibility in the community regarding economic, social and environmental issues (in, Cho, Furey, and Mohr, 2016) More specifically Kim (2014) made six categories of CSR activities such as: (1) environmental stewardship, ( 2) philanthropic contribution, (3) educational commitments, (4) community / employee involvement, (5) public health commitments, and (6) sponsorship of cultural / sports activities (in, Cho, Furey, and Mohr, 2016) Referring to these six categories, it can be said that the greatest essence of the CSR concept is that the company is required to compensate each company for good activities directly. or will not directly affect the community around the company. This is because currently the public needs a lot of information and oversees the company's practices and contributions to the lives of surrounding communities through CSR (Lehtimaki, Kujala, and Heikkinen, 2011).

Furthermore, based on the literature review that researchers have done it can be seen that so far CSR and existing research focuses on several things such as: (1) Research on the influence of CSR on consumer behavior is carried out by Arli and Tjiptono (2013). This research was conducted in Indonesia using survey methods. In this study it can be seen that consumers will be more supportive of companies that carry out CSR with philanthropic concepts such as donations, direct assistance, and volunteerism. Arli and Tjiptono (2013) also added that through CSR companies can promote their products. (2) Furthermore, other studies on CSR discuss much about communicating CSR to the public as practiced by Verboven (2011). Verboven (2011) examines the use of slogans to communicate CSR and corporate identity to the public. Through qualitative research methods using rhetorical theory, it is found that the communication of CSR by chemical industries aims to obtain a "license" from the community so that the company can continue to operate. Next, another research on CSR leads to (3) the relationship between CSR and employees such as research conducted by Smith and Langford (2011). Smith and Langford (2011) use the survey method to find out about this and the results show that CSR carried out by companies can attract prospective employees and can better strengthen the relationship between employees and the company.

Next, other researches on CSR are involved (4) the influence of regulation on the implementation of CSR by companies such as those carried out by Kriyantono (2015). Research conducted by Kriyantono (2015) using this survey method shows that the main purpose of the regulation on CSR is to create social welfare for the community and in its implementation in Indonesia, the person considered the most important in the process of implementing a company's CSR is public relations. Several other studies that also reviewed 
CSR were also carried out by Chapple and Moon (2005) with the aim of (5) observing the implementation of CSR in seven countries in Asia through the website. Chapple and Moon (2005) explained that the implementation of CSR in countries in Asia is homogeneous which is influenced by the stages of state development and globalization. However, it can be concluded that multinational companies in Asia implement CSR more comprehensively in the countries where they operate than their countries of origin. Research on CSR is also carried out by Zoller and Tener (2010) using (6) CSR as a tool for conducting environmental and stakeholder management. Zoller and Tener (2010) conclude that by being a "good neighbor" through CSR, companies can play a central role in making decisions in the community to gain legitimacy from the company's operations and can influence people's perceptions of environmental conditions that may need to be changed or given innovation.

Similarly, Zoller and Tener (2010) stated that CSR is used to shape community perceptions, O'Connnor and Gronewold (2012) and Lehtimaki, Kujala, and Heikkinen (2011) also found similar results. O'Conner and Gronewold stated that (7) by making a comprehensive CSR communication especially on environmental issues for mining companies will help companies to be sustainable. Next Lehtimaki, Kujala, and Heikkinen (2011) also stated from the results of their research that (8) communicating CSR can reduce conflict tension and controversial situations in companies or investors in the company. The utilization of CSR for the benefit of one side of the company is not only revealed by the three studies above. Jamali (2008) also revealed that (9) CSR as a method to approach stakeholders. This is also further strengthened by the results of research conducted by Malin and Pyykkoen (2015) that (10) in the process every part of the company, especially employees, must be able to define CSR well that focuses on welfare.

Based on the explanation of several preliminary studies above, it can be seen that there is no single research on CSR that specifically examines stakeholder opinion through three measurement scales as well as a comprehensive one. Whereas on the one hand CSR through its dimensions has the potential as a medium for dealing with poverty. This refers to the concept of CSR which is defined as a form of corporate social responsibility to the community voluntarily to create social welfare that focuses more on economic problems (Siltaoja, Malin, and Pyykkonen (2015). Furthermore Van Marrewijk (2003) defines CSR as a the relationship of corporate social responsibility to society regarding economic, social and environmental issues (in, Cho, Furey, and Mohr, 2016) More specifically Kim (2014) makes six categories of CSR activities such as: environmental stewardship, philanthropic contributions, educational commitments, community / employee involvement, public health commitments, and sponsorship of cultural / sports activities (in, Cho, Furey, and Mohr, 2016). Other dimensions of CSR are also made by Carroll (1991) in four dimensions: economic, legal, ethical, and philanthropic. In addition to Carroll Dahlsrud (2008) also made five dimensions in implementing CSR namely: environment, social, economic, stakeholder and volunteerism. From these dimensions, an early preposition can be drawn that economics is an important CSR element to be implemented.

However, it seems that CSR research related to economic issues is not much done or has not yet become a focus. This refers to several presentations of previous research related to the focus of research and implementation of CSR. So that it becomes a challenge in itself to be able to show that CSR has the potential to be developed into a poverty alleviation media in the economic dimension of CSR. Especially in CSR there are several supporting dimensions such as community involvement and volunteerism. When these three dimensions are combined, of course economic empowerment can be carried out so indirectly this will help alleviate poverty by making the community empowered.

This argument is also reinforced by the statements of Brammer, He, and Mellahi (2014) that current research on CSR must focus on social problems. This focus is also seen from the problems that are often raised on several companies' websites such as issues about community and the environment, although there are also several other problems such as human rights and employees (Smith, 2017). However, even so, the community is still a dominant topic considering CSR is an integration of the resolution of social and 
environmental problems by the company. Therefore, the social problems raised in this study relate to the problem of community namely poverty.

Of course based on some of the research above it can be concluded that no one has specifically studied and described stakeholder opinions. Even though through the implementation of good stakeholder management can help companies to predict the environment in order to ensure the sustainability of the company in the future. This is also further strengthened by the statement of Bhattacharya, Korschun, and Sen (2009) about understanding the company's stakeholders in CSR as an important agenda. Plus, trace Kriyantono (2014), stakeholder management provides a comprehensive explanation of how to build company relations with various parties related to the company's operational activities to achieve superior performance. Therefore it is important for the company to identify this influence group. On this occasion the author tries to provide an example of stakeholder management. The processing becomes a foundation that must be controlled by the company to be able to control and predict all forms of problems and changes in the environment (Freeman and McVea, 2001). One way that can be done to manage stakeholders is the benefit of CSR as a dialogical media of the company and stakeholders. Stakeholders in this study are specifically beneficiaries of the CSR programs of the five companies.

This urgency is considering CSR is a company program to engage in social problems by contributing and value benefits to economic development and improving people's welfare in the day-to-day operations of the company (Kottler \& Lee, 2004; Iriantara, 2004; Kriyantono, 2016; Turker, 2009). In addition CSR is an important element of corporate dialogue with its stakeholders and researchers find many companies rely on the end result of CSR (Bhattacharya, et al, 2009; Kriyantono, 2015). The final results can be interpreted as a form of community assessment of CSR activities that have been carried out by the company. This assessment can be done by asking public opinion about the CSR program that was rolled out.

Continuing Freeman and McVea's (2001) statement of change in confusion in CSR, the researchers outline that the environment in question is not only limited to the natural environment but also encompasses an environment that deals with social, political and cultural problems. Freeman and McVea (2001) added that stakeholder management is an integrated approach to determine or make a company decision that ultimately the decision is expected to satisfy stakeholders. The word "satisfying" in this context can be seen as a value that the company seeks to fulfill. This value is the basis for the emergence of stakeholder theories which are assumed to be an important part of a business (Freeman, Wicks, and Parmar, 2004). This makes the company must be able to facilitate and bring stakeholders to be able to build shared values and understanding about the related company.

\section{METHODS OF RESEARCH}

Next, enter the research method. The method used is quantitative with a large umbrella of the positivistic paradigm. Next enter the research object. The object of research in this study are five companies in Indonesia, especially those engaged in the oil and gas sector such as: PT. Pertamina Drilling Indonesia, State Gas Company (PGN), PT. Energy Station, Hongkong Sanghai Bank Corporation (HSBC), and PT Sharp Indonesia. This is because according to Himawan (2017) the oil and gas sector contributes greatly to Indonesia by contributing gross domestic product of three to four percent per year. Realistically, if the corporation engaged in oil and gas is also required to be able to provide a balanced contribution in the context of CSR, considering that the corporation is capable of lifting 802,000 barrels of oil per day (Novalius, 2017). Although this amount is an accumulation of all oil and gas corporations in Indonesia, this can reflect that this sector has the ability to be able to carry out CSR more comprehensively. When viewed based on data showing the 10 largest oil and gas companies in Inodenesia, Pertamina is not a company in the first rank in this category but is capable of bearing the title as a company that implements CSR well version of the Kesos RI CSR Forum 2016. In addition to Oil and Gas, researchers also added several companies engaged in banking such as Hongkong and Shanghai Bank 
Corporation (HSBC) and companies engaged in manufacturing such as PT. Sharp Indonesia. These five companies were selected with consideration of accessibility of research data.

In total in the study there were five companies that became the object of research. The five companies are spread in several major cities in Indonesia including: Bekasi, Karwang, Medan, Pontianak, Yogyakarta, Jakarta, Tangerang, Sidoarjo, and Pangkal Pinang. Furthermore, with regard to the number of samples to be taken for this study, it refers to the elaboration given by Prayogo and Hilarius (20110 that for CSR research samples were taken between 75-300 samples. This is considering that the number of recipients of CSR programs is very heterogeneous. Researchers take the upper limit of the sample is 300 respondents in this study. In this study, researchers combined three measurement scales to determine public opinion on CSR program activities that have been carried out by some of these companies. The measurement scale that researchers first used is an indicator that has been built by Dedi Prayogo and Yoseph Hilarius (2010) to evaluate CSR. Prayogo and Hilarius (2010) studied it from the context of sociology and researchers are currently studying from the context of communication and public relations. The indicators built by Prayogo and Hilarius are called the Community Development Index (CD Index) which has six indicators, namely: (1) effectiveness, (2) relevance, (3) sustainability, (4) impact, (5) empowerment, (6) participation).

Furthermore, the second scale that researchers use is the CSR measurement scale developed by Kanji and Chopra (2015). This Chopra Corporate Social Responsibility (KCCSR) Kanji scale is used by researchers to be able to see how far the company has run social responsibility. KCCSR has indicators that enable researchers to be able to identify, classify, analyze and respond to CSR. Some KCCSR indicators include: (1) social accountability and social investment, (2) ethics and human resources, (3) corporate governance and economic responsibility, (4) environment protection and sustainability. The next measurement scale used to evaluate CSR is ISO 2600. ISO 2600 is used to determine public opinion on the implementation of CSR programs based on international standards. This ISO 2600 includes: (1) organizational governance, (2) the environment, (3) labor practice, (4) fair operating process, (5) human rights, (6) consumer issues, (7) community involvement and development. The three scales used by researchers to determine public opinion on the implementation of CSR activities that have been carried out by five companies and nine major cities in Indonesia. The measuring scale is translated into the items in question with a scale of 1 to 4 .

\section{RESULTS OF STUDY}

Kanji Cophra Corporate Social Responsibility (KCCSR). In the first discussion, in this section the researcher enters the scales used to conduct this research. The first scale that the researcher will present is Kanji Cophra Corporate Social Responsibility (KCCSR) which is used to view social media that is successfully obtained by the company through the roll-out of CSR programs. This KCCSR has four main indicators, namely: (1) social accountability and social investment, (2) ethics and human resource, (3) corporate governance and economic responsibility, and lastly (4) environment protection and sustenance ability. The four indicators are assessed through 31 statement items that the researchers detailed in the table below as follows:

The table above research presents along with the calculation of the mean score of each statement item in all four indicators. This score shows the tendency of respondents' answers in each statement. The highest value that the researcher set in this study is 4 and the lowest value is one and with a percentage value $>75 \%$ which means that the opinion of the beneficiary can be said to be good for each indicator used in this research. When viewed from the calculation of the mean score above, all indicators approach the highest value, which means that the community's assessment of CSR programs rolled out by the company is in a good position. 
Table 1 - Calculation of Meanscore CSR Index

\begin{tabular}{|c|c|c|c|}
\hline NO & Index Category & $\begin{array}{l}\text { Mean } \\
\text { Scores }\end{array}$ & $\begin{array}{c}\text { Maximal } \\
\text { Scores }\end{array}$ \\
\hline \multicolumn{4}{|c|}{ Social Accountability And Social Investment } \\
\hline 1 & The company has been transparent and open about its business activities & 3.24 & 4.00 \\
\hline 2 & $\begin{array}{l}\text { The company has provided a system to prevent corruption in the company environment, } \\
\text { including preventing financial abuse and transaction fraud. }\end{array}$ & 3.147 & 4.00 \\
\hline 3 & The company has provided arrangements to produce positive impacts for a better society & 3.137 & 4.00 \\
\hline 4 & $\begin{array}{l}\text { The company has provided facilities for socially responsible investments, such as } \\
\text { education and health facilities }\end{array}$ & 3.143 & 4.00 \\
\hline 5 & The company has provided social accountability within itself to meet public expectations & 3.090 & 4.00 \\
\hline \multirow[t]{3}{*}{6} & The company has considered its social responsibility to the community to be important & 3.307 & 4.00 \\
\hline & Total & 19.064 & 24 \\
\hline & Index Value & $79,433 \%$ & $100 \%$ \\
\hline \multicolumn{4}{|c|}{ Ethics And Human Resource } \\
\hline 7 & The company contributes to campaigns and projects that focus on community welfare & 3.137 & 4.00 \\
\hline 8 & Companies always pay taxes regularly and continuously & 3.150 & 4.00 \\
\hline 9 & The company supports people who want to get additional education & 3.167 & 4.00 \\
\hline 10 & The company provides complete and accurate information about its products to the public. & 3.190 & 4.00 \\
\hline 11 & The company respects the rights of the community as determined by the rule of law & 3.193 & 4.00 \\
\hline 12 & The company has been concerned about environmental problems for its customers & 3.210 & 4.00 \\
\hline 13 & $\begin{array}{l}\text { The company has implemented a transparent system to control labor practices such as: } \\
\text { - Normal working hours } \\
\text { - } \quad \text { Hard and inhumane treatment of labor }\end{array}$ & 3.130 & 4.00 \\
\hline 14 & $\begin{array}{l}\text { The company has successfully implemented a clean and hygienic workplace and safe } \\
\text { working conditions }\end{array}$ & 3.207 & 4.00 \\
\hline 15 & The company does not discriminate against its employees / society for welfare. & 3.173 & 4.00 \\
\hline 16 & The company encourages people to participate in voluntary activities & 3.327 & 4.00 \\
\hline 17 & $\begin{array}{l}\text { The company supports non-governmental organizations (NGOs) overcoming social } \\
\text { problems }\end{array}$ & 3.150 & 4.00 \\
\hline & Total & 35.034 & 44 \\
\hline & Index Value & $79,622 \%$ & $100 \%$ \\
\hline \multicolumn{4}{|c|}{ Corporate Governance And Economics Responsibility } \\
\hline 18 & $\begin{array}{l}\text { The company has interacted with the community in conducting social responsibility } \\
\text { programs (CSR) }\end{array}$ & 3.273 & 4.00 \\
\hline 19 & Company management is very concerned about the needs and desires of the community & 3.110 & 4.00 \\
\hline 20 & $\begin{array}{l}\text { The company has respected the quality of life of the workforce and their families and the } \\
\text { community as a whole }\end{array}$ & 3.003 & 4.00 \\
\hline 21 & Management decisions related to the community are usually fair & 3.103 & 4.00 \\
\hline 22 & The company has achieved its contribution to the country's economic development & 3.063 & 4.00 \\
\hline 23 & $\begin{array}{l}\text { The company has been able to create employment opportunities for the surrounding } \\
\text { community }\end{array}$ & 3.057 & 4.00 \\
\hline & Total & 18.609 & 24 \\
\hline & Index Value & $77.537 \%$ & $100 \%$ \\
\hline \multicolumn{4}{|c|}{ Environment Protection And Sustainability } \\
\hline 24 & $\begin{array}{l}\text { The company has attempted to manage and control risks in the company to control } \\
\text { incidents such as environmental accidents }\end{array}$ & 3.194 & 4.00 \\
\hline 25 & $\begin{array}{l}\text { The company has attempted to publish the environmental impact of its products on the } \\
\text { website or print media so that the public is aware }\end{array}$ & 3.180 & 4.00 \\
\hline 26 & $\begin{array}{l}\text { The company has sought to change the product brand or product value in accordance with } \\
\text { global environmental considerations }\end{array}$ & 3.040 & 4.00 \\
\hline 27 & $\begin{array}{l}\text { The company has sought to cut unwanted product packaging in global environmental } \\
\text { problems }\end{array}$ & 3.097 & 4.00 \\
\hline 28 & $\begin{array}{l}\text { The company participates in activities aimed at protecting and developing environmental } \\
\text { quality }\end{array}$ & 3.423 & 4.00 \\
\hline 29 & $\begin{array}{l}\text { The company has attempted to communicate the environmental effects of economic } \\
\text { actions to certain groups or the wider community }\end{array}$ & 3.067 & 4.00 \\
\hline 30 & Our company targets sustainable growth for future generations & 3.357 & 4.00 \\
\hline \multirow[t]{3}{*}{31} & Our company invests in creating a better life for future generations & 3.387 & 4.00 \\
\hline & Total & 25.745 & 32 \\
\hline & Index Value & $80.453 \%$ & $100 \%$ \\
\hline
\end{tabular}

In more detail the researcher presents the discussion of each indicator as follows. The first indicator measurement scale is Social Accountability And Social Investment (SASI). The value index for the SASI indicator measurement scale is at a value of $79.433 \%$. The value index describes the acceptance and good perception of the implementation of CSR programs from the companies concerned by the beneficiaries of those companies. Based on the results of the index value, it can also be seen that the CSR programs that have been 
rolled out by the sample companies in this study have been considered by the beneficiaries to be able to create a positive impact on the sustainability of beneficiaries and society in general. This can be seen from six question items in this category. Of the six items that are available, the highest assessment is found in the item question about the company's focus related to social responsibility to the community.

The next scale of measuring CSR indicators is the Ethics and Human Resource (EHR). In general, the index value in this indicator is $79.62 \%$. The value index has indicated that the implementation and acceptance of beneficiaries of CSR activities carried out by these companies is quite good. The results of the index value above also indicate that these companies have realized CSR activities in accordance with the applicable law with a fairly good category. Especially about the problem of responsibility to consumers. This means that the company has tried carefully to create environmental security for the beneficiaries around the area of its operation.

The next indicator measurement scale is Corporate Governance and Economics Responsibility (CGER). In general, based on the table above it can be seen that in general stakeholders have perceived that CSR activities carried out by the company have been implemented quite well. This conclusion is drawn based on the index value obtained in this indicator of $77.54 \%$. The lowest perception, although still in good category, arises from CSR activities carried out by the company to the beneficiaries in fair treatment. Beneficiaries have seen that all activities carried out by the company respect the quality of life both from the workforce to the wider community. Assessment of the company's respect for these beneficiaries is derived from an opinion assessment which states that the company has provided interaction space and involves beneficiaries as stakeholders in the existing CSR programs.

The last scale of measuring CSR indicators is Environment Protection and Sustainability (EPS). The final result of the calculation of the index value of this indicator is not much different from the results of the calculation of the three index values of the previous indicator which is still in the range of $50 \%-75 \%$. In this indicator, the index value is $80.45 \%$ which means that in general the perception of beneficiaries regarding the implementation of CSR programs by the company at a fairly good level. Beneficiaries based on the highest means scores calculated that the company had done well enough to develop environmental quality. This assessment arises with one strong reason that the company is considered to have been present among the beneficiaries with its various programs aimed at improving the quality and welfare of beneficiaries as company stakeholders.

Next, in more detail the researcher presents a diagram of the results of the research related to the perception of the beneficiaries of CSR activities carried out by the company based on the four scales of CSR measurement indicators, as follows:

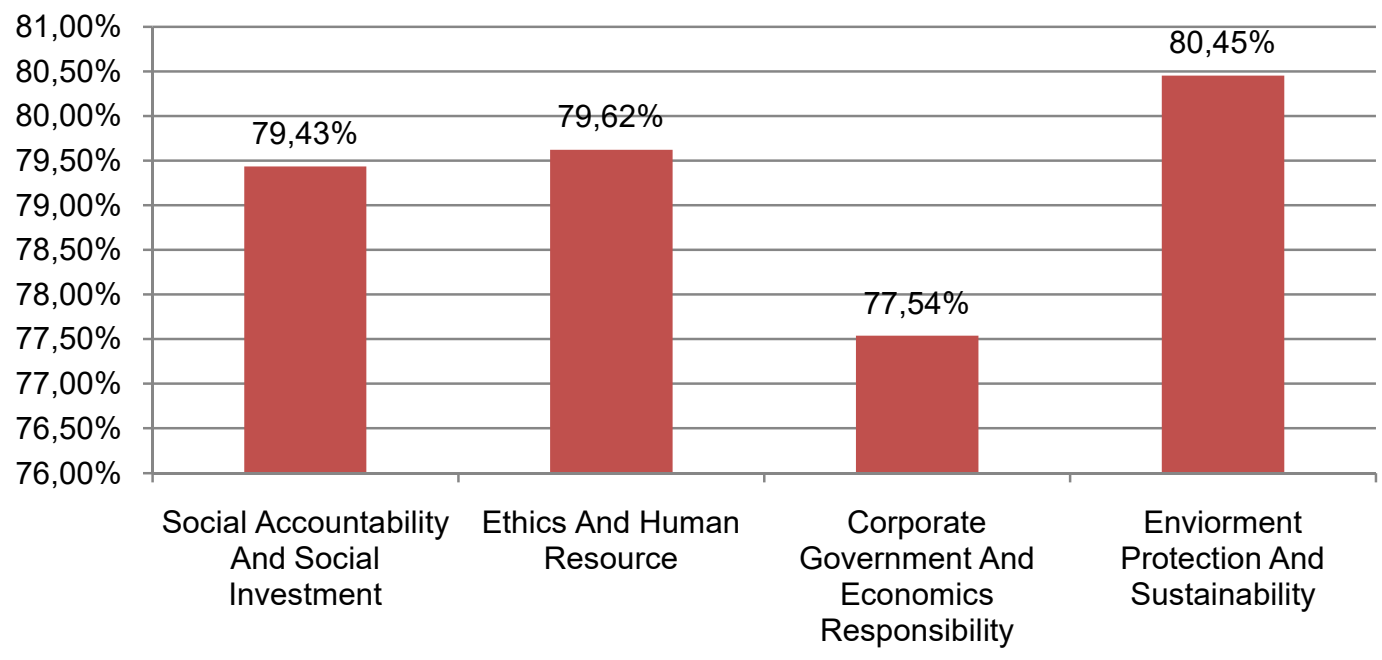

Figure 1 - KCCSR Scale 
In general, the overall indicators are in the range of $50 \%-75 \%$ which means that the overall perception of the welfare of the beneficiaries as stakeholders of the company towards CSR activities that have been carried out by the company is at a fairly good level. Based on the data above, it can also be seen that the highest level of perception by beneficiaries is that the environmental responsibility of the company is considered good enough. Beneficiaries as stakeholders of the company consider that the company has carried out environmental responsibility and future generations. In addition, the difference in index value of one indicator with other indicators is not much different, which means that four indicators on this scale are responded positively by the beneficiaries.

The beneficiary's opinions reflected show consistency of assessment on each indicator. In the first indicator of social accountability and social investment (SASI) the positive response that emerges is that the beneficiary assesses that the company has demonstrated its responsibility to the community through each CSR program that was rolled out. Or in other words, the welfare of beneficiaries as company stakeholders assesses that the company has placed social responsibility as an important part of the company. Based on the second indicator of ethics and human resources (HER), what is meant by social responsibility that has been implemented by the company well is social responsibility regarding environmental issues. This positive response was also established by the company because the welfare of beneficiaries as stakeholders of the company felt that they had been given space and involved in the process of implementing CSR programs. The positive response researchers read from the indicators of corporate governance and economic responsibility (CGER). Because of this, the welfare of the beneficiaries as stakeholders of the company responds to all actions taken by the company through the existing CSR programs is a form of corporate business to help protect and develop the quality of life of the community.

Corporate Social Responsibility (CSR) Index. The second scale that researchers use in this study is the CSR Index built by Prayogo and Hilarius (2011). This scale is used to determine the effectiveness of a CSR program in poverty alleviation. There are six main indicators on this scale namely: effectivity, relevance, sustainability, impact, empowerment, and participant. Researchers use these six indicators to examine six fields at the same time in implementing CSR such as: education, health, economy, environment, infrastructure, and donations. In more detail the researchers submit in the table below as follows:

Table 2 - Corporate Social Responsibility Index

\begin{tabular}{|c|c|c|c|c|c|c|c|c|c|c|}
\hline \multirow{3}{*}{ No. } & \multirow{3}{*}{ Category } & \multicolumn{6}{|c|}{ Parameters } & \multirow{3}{*}{\multicolumn{2}{|c|}{ Total }} & \multirow{3}{*}{$\begin{array}{c}\text { Maximal } \\
\text { Score }\end{array}$} \\
\hline & & \multicolumn{6}{|c|}{ Mean Score } & & & \\
\hline & & Education & Health & Economy & Environment & Infrastructure & Charity & & & \\
\hline 1. & Effectiveness & 3.130 & 3.163 & 3.113 & 3.243 & 2.990 & 3.223 & 18.862 & $78.441 \%$ & 4.00 \\
\hline 2. & Relevance & 2.973 & 3.157 & 3.003 & 3.223 & 2.953 & 3.153 & 18.462 & $76.925 \%$ & 4.00 \\
\hline 3. & Sustainability & 3.020 & 2.863 & 2.940 & 3.153 & 2.890 & 3.087 & 17.593 & $73.304 \%$ & 4.00 \\
\hline 4. & Impact & 2.910 & 3.103 & 3.010 & 3.213 & 2.983 & 3.160 & 18.379 & $76.579 \%$ & 4.00 \\
\hline 5. & Empowerment & 2.997 & 3.127 & 3.073 & 3.257 & 3.013 & 3.187 & 18.654 & $77.725 \%$ & 4.00 \\
\hline 6. & Participant & 3.053 & 3.173 & 3.113 & 3.313 & 3.083 & 3.230 & 18.965 & $79.020 \%$ & 4.00 \\
\hline \multirow{2}{*}{\multicolumn{2}{|c|}{ Total }} & 18.083 & 18.486 & 18.252 & 19.402 & 17.912 & 19.04 & \multirow{2}{*}{\multicolumn{2}{|c|}{ Total }} & 24 \\
\hline & & $75.345 \%$ & $77.441 \%$ & $76.05 \%$ & $80.841 \%$ & $74.633 \%$ & $79.333 \%$ & & & $100 \%$ \\
\hline
\end{tabular}

Based on the table above can be seen the implementation of CSR by companies in Indonesia both by category and by field. One piece is charged for the category of participants in the maximum category of $79.020 \%$. Furthermore, in terms of area the highest percentage in the environmental sector is $80,841 \%$.

From the diagram above it can be seen that based on the participant category is the highest indicator. This shows that the involvement of the community in the process of implementing CSR is quite good. However, based on field data owned by researchers, the involvement of beneficiaries as stakeholders of this company is only done when the CSR program is implemented. Beneficiaries have not been involved in the planning phase. However, the program was considered effective $(78.44 \%)$ by stakeholders because the program had relevance $(76.93 \%)$. So the impact $(76.60 \%)$ is also good for the community, with one of them being able to empower or empower $(77.73 \%)$ the community. However, the 
biggest homework in implementing a program is that sustainability issues that are still legible have the lowest value among other categories, namely $73.30 \%$. Although mathematically the value for sustainability is in a good category, of course this is a separate note in the future. Based on the data above, the researcher tries to find a cause of contradiction, meaning that the CSR implementation system is not as long as it is free from the top down system. So the results are contradictory. Researchers traced further this matter and found new facts and hypotheses that require further research in the future. All existing programs from the six companies are implemented without involving stakeholders who are beneficiaries of the program in the planning stage. So even though the participant's high value of sustainability is still a bit far behind.

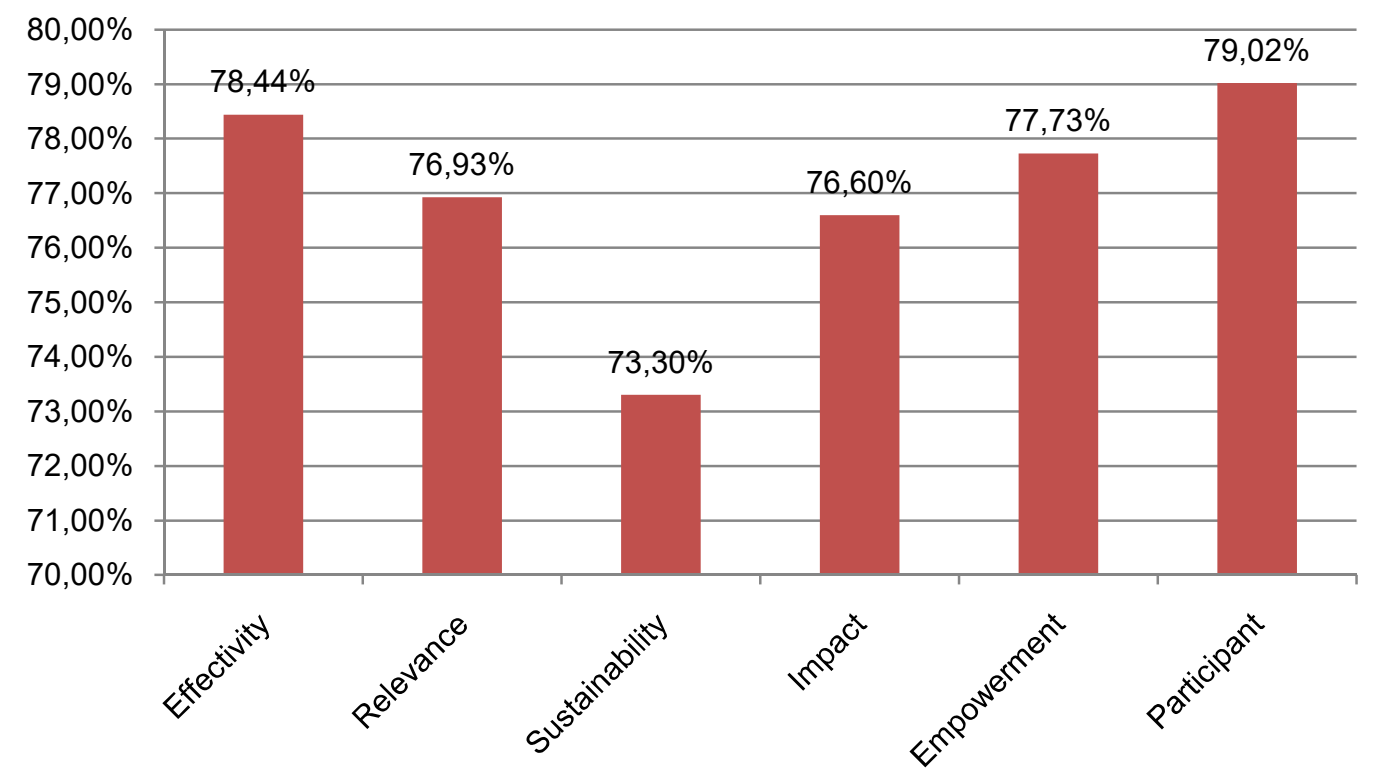

Figure 2 - Distribution Frequency CSR Index Based on Category

ISO 2600 is a general reference standard that must be met by the company in the CSR implementation process. In this study, researchers want to measure public perceptions of the implementation of CSR through a number of indicators that are established internationally through ISO 2600. In the table below the researchers describe the results of the survey and the calculation of the mean score of each indicator as follows:

Table 3 - ISO 26000

\begin{tabular}{|l|l|l|l|}
\hline No & Indicator & Maximal Score & Minimal Score \\
\hline 1. & Organizational Government & 4.00 & 3.167 \\
\hline 2. & The Environment & 4.00 & 3.083 \\
\hline 3. & Labor Practice & 4.00 & 3.258 \\
\hline 4. & Fair Operating Practice & 4.00 & 3.200 \\
\hline 5. & Human Rights & 4.00 & 3.250 \\
\hline 6. & Consumer Issue & 4.00 & 3.050 \\
\hline 7. & Community Involvement and Development & 4.00 & 3.340 \\
\hline \multicolumn{2}{|}{ Total } & 32 & 22.348 \\
\cline { 3 - 4 } & $100 \%$ & $69.837 \%$ \\
\hline
\end{tabular}

From the table above it can be seen that the overall indicator gets a good assessment from the stakeholder community. Furthermore, if accumulated in percentage form, the amount can already be included in either category. Because the range of good categories is in the percentage range of $50-75 \%$. Somewhat different from other measurement scales, on a measurement scale that uses ISO, environmental issues occupy the lowest rating and followed by consumer issues also get a low rating. 
Still referring to the diagram above, it can be seen that involving the community in the process of implementing high CSR. It is evident from the seven indicators that there are indicators of community involvement and development getting the best assessment. This further strengthens that currently the implementation of the CSR system no longer uses a top-down system but has implemented a bottom up system. However, even so, this high level of community involvement has only occurred in the implementation stage and has not yet begun from the planning stage.

\section{DISCUSSION OF RESULTS}

CSR Opinion Stakeholders through 3 Measuring Scales: KCCSR, CSR Index, and ISO 2600. The main subjects in this study were beneficiaries as stakeholders of companies that received CSR programs from companies. Beneficiaries as company stakeholders in this study are defined as "key drivers" to achieve company reputation (Bussy, 2008). The reputation of the company in this context the researcher means as an assessment or stakeholder opinion on CSR programs that have been implemented by the company. This definition more clearly describes the condition of the beneficiary as a group or individual that has the potential to influence or be influenced by activities carried out by the company (Coombs, 2007). Because of the reciprocal nature of the beneficiaries as stakeholders of the company and the company, this raises the concept of interconnection between the two. So it can be concluded that stakeholders are the main target of every activity carried out by the company (Freeman, 1984; Kriyantono, 2015; Seitel, 2001).

The explanation above explains that the measurement scale of the opinion of the beneficiaries as the company's stakeholders on CSR programs can be done by knowing the stakeholder perceptions of CSR activities carried out by the related companies. In addition, by understanding stakeholder opinion which also includes stakeholder trust and knowledge (Galloway \& Aidoo, 2005), it is hoped that it can create a mutually beneficial understanding (mutual understanding) between stakeholders and related companies (Cultip, Center, \& Broom, 2011). So with this trust and mutual understanding will bring support for the company. Based on the above understanding, the researcher conducted a form of opinion study to find out stakeholder perceptions of CSR activities carried out by companies in Indonesia as a communication medium to get support from stakeholders from the CSR programs rolled out.

The results of this study indicate that stakeholders have a fairly good perception of CSR activities that have been carried out by companies in Indonesia. This means that there has been a mutual understanding between stakeholders and related companies. In general, the three scales that researchers use to conduct this evaluation study show results in good categories. Of the three scales that researchers use, the KCCSR and CSR Index show that community members in this context are represented by stakeholders who agree that the company has a high commitment to CSR programs related to environmental issues. However, for the scale that researchers adopted from ISO 2600 the results were no different. On this scale the highest assessment is the attitude of openness of the company with evidence of giving space to the public to actively participate in CSR programs that are being rolled out. This also means that CSR programs that are rolled out by the company have been able to become a medium of communication for companies to be able to engage in community psychology. This statement is strengthened by research findings

Basically CSR can be an important element for companies to communicate with the community and not infrequently many companies from various research results rely heavily on CSR to establish relationships with stakeholders (Battacharya, et al, 2009; Kriyantono, 2015). This is evidenced by the measurement results of two of the three scales used that the company has actively engaged the community in every CSR program rolled out. Both on the CSR Index scale through the category of participant in all fields and the scale of ISO 26000 with indicators of community involvement and development all get the highest assessment by the community at each measurement scale. This shows that CSR is really used by companies as a communication medium. Of course this will help the company to get support 
from stakeholder. From the research that the researchers did, this was also measured by the companies that were used as the sample of the study in this study. So that it can also be understood that CSR communication patterns rolled out today are no longer fully top down but have become bottom up by accommodating and involving the community in the process. Although there is still a large record in the process, community involvement has only begun in the implementation phase rather than planning.

This should be a separate consideration for the company because the process of bottom-up communication certainly has a significant impact on the overall aspects of the CSR program being rolled out. The CSR process that is bottom-up provides space for stakeholders to be able to express their opinions. Because of this, the corporate governance and economic KCCSR dimensions of the community provide the highest assessment of items of statement that the company has interacted with the community. This bottom-up communication process has implications for the effective and relevance assessment on the CSR Index scale which shows that in all fields get a good assessment. Again, this shows that CSR can be used as a medium of communication with the community to get support. Of course, with a note that the company must open a space of participation for the community so that the CSR program that is rolled out as a communication medium runs effectively by finding the relevance of community needs which are then translated into CSR programs. At present, this is a good assessment by the community on the scale of ISO 26000 to be precisely the indicator of human right on the number of good acceptance by the community.

However, even though the three scales used in each indicator, category, and field under study in CSR are in good judgment, there are several indicators that have a low rating compared to indicators, categories and other fields. This can be seen from the acquisition of the value index listed from the KCCSR and ISO 26000 which has the lowest revenue average even though it is still in a good category. Examples of Corporate Governance and Economic Responsibility in KCCSR have the lowest index value among the three other indicators, but the assessment of the community against this indicator is still at a pretty good level. In this indicator, the community considers that with the CSR being rolled out by the company, the company is assessed that the economic social responsibility that has been carried out by the company to direct stakeholders such as investors, employees and customers is quite important but not more than other indicators. This is also supported by the results of the scale in ISO 2600 that the consumer issue is the lowest point, even though it is still in a good category compared to the other seven indicators in ISO 26000.

The next category that gets a low rating that appears from the CSR Index is the sustainability program. Of the six existing fields such as education, health, economy, environment, infrastructure, donations, only two areas with high sustainability programs are in the field of environment and education. Based on the achievement of 3,153 figures for the environmental field and 3.02 for the education sector, this indicator is also perceived by the public at a fairly good level which means that the company has been able to implement this indicator quite well. However, of course, looking at the other four areas that value towards the sustainability category are still relatively low even though they are still in a good range, this has become a separate homework for program organizers to be able to create CSR programs in every field that has high sustainability. This is also a matter worth considering because it is directly proportional to the sustainability program, so the social legitimacy of the community can also last longer.

Overall, the community's assessment of CSR activities that have been carried out by several companies in Indonesia at a good level or in other words that the CSR program rolled out has been considered effective.. This also indicates that CSR is indirectly a good medium of communication and has a significant impact on the relationship between the community and the company. Besides that the implementation of CSR properly will be able to help the dialogue process between the company and the community better to be able to achieve mutual understanding which ultimately gives birth to social support for the company.

Corporate Social Responsibility: A Future Potential Public Relations Communication Activity. The main challenge in this study is to put empirically CSR as a public relations activity in a communication perspective. In addition in this study, researchers are also 
obliged to be able to describe the potential of CSR as a trend of CSR activities in the future to create the image and reputation of the company. First for the problem of occupying CSR as a study of communication can be seen from the overall results of the opinions of beneficiaries as stakeholders of the company who generally agree that the company has implemented CSR well. This opinion shows that beneficiaries as stakeholders of the company have been able to understand the message in CSR activities.

It should be understood at the outset that CSR in this context is not only a product of the company that aims to create a social welfare for its stakeholders, but also a medium of communication. If CSR is understood as a communication medium, there is a message in CSR. Borrowing the Laswell transmission model, it can be considered a communicator in this communication process is the company represented by public relations as the communication manager, the message that is brought is CSR creates walfare and gives stakeholders benefits through various fields and indicators, the media used is CSR programs, communication are the beneficiaries as company stakeholders, and the effect of communication that emerges is a good opinion of benefiting from the existing CSR programs.

Based on the description above, it can be understood in terms of communication that CSR works well and has the potential to serve as a communication medium for companies to shape the image and reputation of the company. Moreover, CSR as a communication medium has not only fulfilled the communication aspect in the transmission model, but has also led to the two way communication model. This is evidenced from the three sakala used by researchers to find out the opinions of beneficiaries as stakeholders of the company towards all existing CSR activities, showing positive significant results on participant indicators in the CSR Index, community involvement and development at ISO 2600, and ethics and human resources on KCCSR. The three indicators in each scale discuss the company's efforts to provide dialogue space for beneficiaries as company stakeholders. This dialogue space can be interpreted as a form of communication between beneficiary companies as company stakeholders.

This form of communication creates a sane of belonging for beneficiaries as company stakeholders. This high Sanse of belonging is able to make stakeholders to the side with the company and provide support. This provides two benefits for the company. First, the company benefits from getting a good image and reputation. Second, the assessment of a good social track record will certainly be able to help companies in the future if they experience a crisis. That is, CSR becomes a communication medium that can provide two benefits at once in one action. Plus, if the implementation of CSR is done appropriately, the public relations function as a communication agent can be done well with two good neighbors that have a big ear. The concept of good neighbor and big ear will be able to help public relations and question the environment and anticipate things that might end the image and cause of crisis. When the overall CSR activities have been carried out properly and ensure the beneficiaries as stakeholders have been well involved and created of belongings, the next task is to maximize the potential of the medium in order to create an image and a good corporate reputation. is to do publications and media media relations. The purpose of this action is to report publicly on the CSR actions that have been carried out by the company. This aim to convey the company is focused and good tendency to maintain and manage the environment. Of course, the initial prediction of the results of this study will provide benefits for the company. This is a public relations activity in the future by utilizing CSR as a communication medium to predict and manage the environment in order to create an image and reputation for the company.

\section{CONCLUSION}

In general, the results of this study indicate that the beneficiaries as stakeholders of the company provide positive value by eliminating the value range of three quarters of the percentage that is on the indicators in each field. This shows that CSR has a high potential as a medium of communication. This argument is supported by data that the value of participation of beneficiaries as stakeholders of companies occupies a high rating on a scale. 
This means that CSR has been carried out with a bottom-up model by the company. This model is then able to create a system of belongings for stakeholders towards the company.

Furthermore, based on the six existing CSR fields such as economics, education, environment, health, infrastructure, and donations, the highest considered to have been implemented properly by the company is the environment. This result also relates to the type of company that is the object of research is a mining company. Because of this, the results will be in line that for the type of companies engaged in mining, more will be concentrated on environmental problems.

Other findings that the researchers are able to describe as a result of this research are that CSR carried out by this company is a public relations activity that can be used as a way to predict the environment as a reference for composing a preventive action for potential crisis in the company. This is due to the fact that through CSR the company can find out about the situation of stakeholders and how to manage it. Referring to all these things can be taken a big conclusion that in the future CSR can be used as a trend of public relations activities in order to shape the image and reputation of the company and as a media to predict and control the environment as a preventive measure of a crisis that might befall the company. This high participation rate can also be utilized by the company with the concept of community involution to maintain all the good relationships that have been established between stakeholders and the company. Following up on these results, in the future there are several studies that can be done to complement the results of the research including: (1) Conducting research in the context to compare the practice of implementing CSR in the state-owned and private institutions. This aims to be able to become an input to the CSR regulations in Indonesia. (2) Test Try the Community Involvement concept to convey the message in forming a sustainability program in every existing CSR program. Lastly, (3) conducting a research study on the analysis of CSR and public relations to see the level of awareness of public relations in utilizing CSR as a communication medium.

\section{REFERENCES}

1. Arli, D., \& Tjiptono, F. (2013). Does corporate social responsibility matter to consumers in Indonesia?. Social Responsibility Journal, 10 (3), 537-549

2. Bhattacharya, C.B., Korschun, D., \& Sen, S. (2009). Strengthening stakeholder company relationships through mutually beneficial corporate social responsibility initiatives. Journal of Business Ethics, 85, 257-272.

3. Brammer, S., He, H., \& Mellahi, K. (2014). Corporate social responsibility, employee organizational identification, and creative effort: the moderating impact of corporate ability. Group And Organization Management, 1-30.

4. Chapple, W., \& Moon, Jeremy. (2005). Corporate social responsibility in asia: A seven country study of csr website reporting. Business \& Society, 4 (44), 415-441

5. Cho, M., Furey, L. D., \& Mohr, T. (2016). Communicating corporate social responsibility on social media: strategies, stakeholder s, and public engagement on corporate facebook. Business and Professional Communication Quarterly, 1-18.

6. Coombs, W. T. (1995). Choosing the right words: The development of guidelines for the selection of appropriate crisis-response strategies, Management Communication Quarterly, 8(4), 447-476.

7. Dawkiin, C., \& Ngunjuri, F.W. (2008). Corporate social responsibility reporting in south africa: Descriptive and comparative analysis, Journal Of Business Communication, 45 (3), 286-307.

8. Dincer, B., \& Dincer, C. (2013). Corporate social responsibility communication and perception: Media and risks, International Journal of Academic Research in Business and Social Sciences, 3(4), 207-224.

9. Freeman, R.E., Wicks, A.C., \& Parmar corporate objective revisited". Organization Science, 15 (3), 364-369.

10. Hupperts, P. \& Kroder, H. (2013). The implementation of SR: Best practice and tools for ISO 26000. Netherlands:Nederlands Normalisatie-Instituut. 
11. Ika. (23 November 2016). Indonesia belum mampu mengurangi angka kemiskinan. Kementrian PPN/ Bappenas. Diakases dari www.sdgsindonesia.or.id

12. Jamali, D. (2008). A stakeholder approach social responsibility: A fresh perspectiveinto theory and practice. Journal Of Business Ethics, 82, 213-231

13. Kanji, G., \& Chopra, P. (2010). Corporate social responsibility in a global economy. Total Quality Management \& Business Excellence, 21(2), 119-143.

14. Kriyantono, R. (2015). Public relations and corporate social responsibility in mandatory approach era in indonesia. Procedia Social and Behavioral Sciences, 2 (11), $320-327$.

15. Kriyantono, R. (2012). Public relations writing. Jakarta: Prenada Media

16. Kriyantono, R. (2015). Public relations, issue, dan crisis management: Pendekatan critical public relations, etnografi kritis, dan kualitatif. Jakarta: Kencana Prenada.

17. Kriyantono, R. (2008). Public relations writing: Teknik produksi media public relations dan publisitas korporate. Jakarta: Kencana Prenada.

18. Kriyantono, R. (2014). Teori public relations perspektif barat dan lokal: Aplikasi penelitian dan praktik. Jakrta: Kencana Prenada.

19. Lehtimaki, H., Kujala, J., \& Heikkinen, (2011). Corporate responsibility in communication: empirical analysis of press releases in a conflict. Business Communication Quarterly, 7 (4), 432-449.

20. Gupta, A.D. (2012). Corporate social responsibility and strategy: a bird's eye view. Global Business review, 13 (1), 153-165

21. O'Connor, A., \& Gronewold. (2012). Black gold, green earth: An analysis of the petroleum industry's csr environmental sustainability discourse. Management Communication Quarterly, 27 (2), 210- 236.

22. Orlitzky, M., \& John D.B. (2001). Corporate social performance and firm risk: A metaanalytic review. Business and Society, 40 (4), 369-396.

23. Purbaya, A.A. (21 September 2015). Ada 19 kementrian urus kemiskinan. Detik Finance. Diakses dari www.finance.detik.com

24. Prayogo, D. (2011). Evaluasi program corporate social responsibility dan community development pada industri tambang dan migas. Makara Sosial Humaniora, 15 (2), 43-58

25. Prayogo, D., \& Hilarius, Y. (2012). Efektivitas program csr/cd dalam pengentasan kemiskinan; studi peran perusahaan geotermal di jawa barat. Makara Sosial Humaniora, (12) 1, 1-22.

26. Saputro, E.P. (5 Januari 2017). Problem kemiskinan 2017. Media Indonesia. Diakses dari www.mediaindonesia.com

27. Sen, S., \& Bhattacharya, C.B. (2001). Does doing good always lead to doing better? Consumer reactions to corporate social responsibility, Journal of Marketing Research, 38(2), 225-243.

28. Sharma, J.P. \& Khana, S. (2015). Corporate social responsibility, corporate governance and sustainability: synergies and inter-relationships. Indian Journal of Corporate Governance, 7 (1), 14-38.

29. Smith, K.T. (2017). Longitudinal analysisiseper corporate social responsibility on company websites. Business And Professional Communication Quarterly, 80 (1), 70-90.

30. Siltaoja, M., Malin, V., \& Pyyokkonen. (2015). 'We are all responsible Governmentality and responsibilized subjects in corporate social responsibility. Management Learning, 46 (4), 444-460.

31. M. Suastha, R.D. (21 Juli 2016). Riset temukan kualitas csr perusahaan indonesia rendah. CNN Indonesia. Diakses dari www.cnnindonesia.com

32. Tesler, L.E., \& Malone, R.E. (2008). Corporate philanthropy, lobbying, and public health policy, American Journal of Public Health, 98(12), 2123-2135.

33. Thaha, R. (4 Juli 2016). Csr kw dan csr original. Forum CSR Kesos. Diakses dari www.forumcsrkesos.or.id

34. Vanhamme, J., \& Grobben, B. (2009). "Too good to be true!" The effectiveness of CSR history in countering negative publicity. Journal of Business Ethics, 85, 273-283.

35. Verboven, H. (2011). Communicating csr and business identity in the chemical industry through mission slogans. Business Communication Quarterly, 74 (4), 415-431. 
36. Widiyanto, U. (19 September 2015). 17 goal dokumen pbb tentang tujuan pembangunan berkelanjutan. Tempo. Diakses dari www.tempo.com

37. Wulandari, F. (15 Juni 2016). Bayanyak perusahaan indonesia yang belum peduli csr. Tribun Bisnis. Diakses dari www.tribunnews.com

38. World Business Council For Sustainable Development (2010)

39. Zatnika, A.M. (10 Mei 2015). Kementrian sosial tambah ditjen untuk urus fakir miskisn. Kompas. Diakses dari www.kompas.com

40. Zoller, H.M., \& Tener, M. (2010). Corporate proactive as adiscursive fiction: Managing environmental health activism and regulation. Management Communication Quarterly, 24 